\title{
A LITERATURA-TERREIRO NA CENA HIP HOP AFROBAIANA
}

\author{
José Henrique de Freitas Santos ${ }^{1}$
}

Resumo: Este artigo propõe o conceito de literatura-terreiro, através da análise de produções artísticas do movimento hip hop que se vinculam aos valores civilizatórios afro-brasileiros, bem como às noções de encruzilhada e ancestralidade presentes nas religiões afro-brasileiras. Com este objetivo, utilizaremos as considerações teóricas de Eduardo Oliveira sobre a filosofia da ancestralidade; Gunther Kress e Van Leween sobre multimodalidade; Amarino Queiroz e Paul Zumthor, sobre oralidade e performance.

Palavras-Chave: Literatura-terreiro; Hip hop; Opanijé; Nelson Maca; EncruziIhada.

Abstract: This paper proposes the concept of "terreiro-literature", through the analysis of artistic production of hip hop movement that binds to AfricanBrazilian civilizing values and to notions of ancestry and crossroads in African-Brazilian religions. With this goal, we use the theoretical considerations by Eduardo Oliveira on the philosophy of ancestry; Gunther Kress and Van Leween on multimodality; and Amarino Queiroz and Paul Zumthor, on orality and performance.

Keywords: Terreiro-literature; Hip hop; Opanijé; Nelson Maca; Crossroads.

Jogando uma pedra ontem, ele matou o pássaro hoje (Oriki de Exu). A Arte que liberta não pode vir da mão que escraviza (Sérgio Vaz).

\section{INTRODUÇÃO}

Este trabalho propõe o conceito de literatura-terreiro, a partir da desconfiança de que há uma dada produção artística literária que desafia os limites da crítica, do comparativismo e mesmo dos estudos de cultura tradicionais, convocando-nos, em vez da certeza metodológica das estruturas e sistemas, a errar nas encruzilhadas dos fios em que esses textos se tecem para melhor compreendê-los, sem necessariamente apreendê-los. Desta forma, sob a advertência imediata também da insuficiência do exercício

1 Professor Adjunto do Departamento de Letras Vernáculas do Instituto de Letras da Universidade Federal da Bahia (IL/UFBA), Salvador-Bahia-Brasil. Doutor em Teorias e Crítica da Literatura e da Cultura pela UFBA. Coordenador do grupo de pesquisa Rasuras: estudos de práticas de leitura e escrita, lotado no IL/UFBA; áreas de atuação: Literaturas de língua portuguesa, língua portuguesa, letramentos, estudos culturais, estudos etnicorracias. Endereço eletrônico: henriquebeat@gmail.com. 
crítico que aqui se fará, pelas restrições que cerceiam qualquer olhar mesmo sob rasura, ateremo-nos primeiro a um afro-graffiti de Marcos Costa (arte-educador, grafiteiro de formação, artista plástico graduado pela UFBA), depois, em especial, tomaremos alguns trechos de uma canção do grupo de rap Opanijé e fragmentos dos trabalhos do poeta, professor e líder do Coletivo Blackitude: Vozes negras da Bahia, Nelson Maca, para discutirmos a emergência da literatura-terreiro na cena hip hop baiana.

Os terreiros, locais de culto das religiões de matriz africana, mesmo historicamente marginalizados, sempre impregnaram com seus saberes e sabores as veias culturais da cidade de Salvador e de diversas cidades do Brasil, já que eles não se restringem aos ritos de celebração aos orixás, mas, de acordo com Vivaldo Costa Lima (LIMA, 2010), legam às malhas urbanas suas cosmovisões, estéticas e éticas. No entanto, apesar de a literatura escrita que emana desses espaços sagrados constituírem-se como literatura-terreiro, sendo Mãe Stella de Oxóssi, Mestre Didi, Ildásio Tavares e outros escritores-membros da comunidade-terreiro, representantes mais evidentes desse segmento, aqui nos interessa pensar em uma modalidade ainda mais rasurante dessa literatura: o rap em seu diálogo com a lógica dos terreiros através dos elementos do hip hop ${ }^{2}$. Interessa-nos a pregnância afrodiaspórica do terreiro no hip hop que sampleia ${ }^{3}$, nas pick-ups ${ }^{4}$ e no rap, a oralidade dos contos e adágios do candomblé e outras religiões de matriz africana; que sampleia, no grafitti, os grafismos ancestrais desde a África Antiga; que sampleia, no break, o corpo em transe, em trânsito, com todos os seus signos em rotação, desfazendo as fronteiras fluidas entre o próprio e o alheio, entre si mesmo e a divindade, já que o próprio corpo torna-se espaço-terreiro.

2 O hip hop é um movimento músico-cultural que tem diversas narrativas de origem, sendo a mais forte a reunião nos guetos negros dos Estados Unidos como o Bronx de experiências dos negros norte-americanos com migrantes latinos vindos da Jamaica e outros países da América Central. Afrika Bambaataa, nome artístico do afro-americano Kevin Donavan, é considerado um dos responsáveis por reunir o MC (Mestre de Cerimônia, cantor), o rap (letra da música que é falada-cantada); o DJ (o sujeito que comanda o aparelho de som chamado pickup) e o graffiti (escrita urbana que é uma mistura de artes visuais e escrita, originalmente realizada nas paredes dos centros urbanos). Muitos rappers hoje defendem um quinto elemento que seria a consciência social, ou seja, a atitude.

3 Sampler é um aparelho que armazena sons (samples). No rap, os samples correspondem geralmente a fragmentos de outras canções que são reordenadas para a produção de um outro texto-sonoro.

4

Toca-discos próprio para o DJ que permite uma maior manipulação dos sons.

172 Número temático: Literatura, cultura e memória negra. A Cor das Letras - UEFS, n. 12, 2011 
No livro Letramentos de reexistência (2011), Ana Lúcia Silva Souza mapeia exatamente a reexistência etnicorracial dos jovens negros nas periferias brasileiras por meio dos quatro elementos artísticos que integram o hip hop, reconhecidos pela autora como importantes agentes de letramento: o DJ (disc-jockey, responsável pela operação dos aparelhos eletrônicos que produzem a base sonora para o canto do rap - poesia oral ritmada canto-falada pelos rappers), o MC (mestre de cerimônias), o/a B-boy/B-girl (dançarino/a de break - ritmo quebrado no qual o corpo pode mover-se rapidamente ou ainda simular as perfomances dos deslocamentos de robôs, dentre outras possibilidades) e o/a grafiteiro/a (artista responsável pelos diversos grafismos que vão desde as referências alfabéticas em diversos formatos a imagens que flertam com as artes plásticas urbanas). Ao conectar-se com uma política anti-racista e de autoafirmação etnicorracial negra, através dos elementos do hip hop, os letramentos de reexistência tornam-se também letramentos negros ${ }^{5}$, vinculando-se ainda aos valores civilizatórios afro-brasileiros, elementos-chave na escritura da literaturaterreiro.

\section{LITERATURA COMO DIFERENÇA: DESAFIOS DA CRÍTICA LITERÁRIA CONTEMPORÂNEA}

A escolha da literatura-terreiro como nosso sujeito-objeto de investigação traz de imediato três grandes desafios:

O primeiro é o confronto dos valores civilizatórios afro-brasileiros (circularidade, religiosidade, corporeidade, musicalidade, memória, ancestralidade, cooperativismo, oralidade, energia vital e ludicidade) com a colonialidade do poder e do saber (MIGNOLO, 2003) que marca a tradição crítica literária, já que trataremos rap como literatura afro-performática, sem questionar esse estatuto, aliás rap (Rhythm and Poetry) significa ritmo e poesia, portanto nos recusaremos, ao tratar da literatura-terreiro no hip hop, de distinguir música e poesia, escrita e performance corporal. Na cosmogonia africana e afro-diaspórica, essas dissociações ferem os princípios

5 Os letramentos negros são os usos sociais das leituras e escritas dispersas dentro e fora do ambiente escolar que atuam de forma crítica em favor das reexistências da população negra, por meio do reconhecimento dos valores civilizatórios afro-brasileiros, de uma política anti-racista e da autoafirmação identitária negra. Eles voltam-se também contra aquilo que Florence Carboni e Mário Maestri chamam de escravização da linguagem, ou seja, a impregnação do signo linguístico por sentidos subalternizantes que se naturalizam e se disseminam produzindo perigosas hierarquias linguísticas. 
multimodais e estéticos em que a leitura e a escrita, bem como a literatura são realizadas, sobretudo para um gênero nascido da confluência de diversas experiências artísticas de negros migrantes da América Central e afroamericanos nos guetos dos EUA, pelo menos essa é a versão mais forte da história que dá conta dos começos possíveis do rap.

A segunda questão é que, até janeiro de 2012, nem Nelson Maca publicou livro de poesia, nem o grupo Opanijé lançou disco, apesar do trabaIho de ambos ser amplamente conhecido na cena hip hop de Salvador e também em outras capitais brasileiras: quem frequenta o Sarau Bem Black (recital de poesia com microfone aberto ao público), no Sankofa African Bar, às quartas, no Pelourinho (Salvador/Bahia), conhece os poemas de Maca e é capaz até de recitá-los, comprovando outra forma de edição que não passa necessariamente pelo papel, exigindo, portanto, outro modus operandi para se analisá-los; no caso do Opanijé, grupo de rap constituído por Lázaro Erê (voz e letras), Rone Dum-Dum (voz e letras), Dj Chiba D (toca-discos) e Zezé Olukemi (percussão), além da responsabilidade de tocar e cantar para que Exu "abra os caminhos" de todo Sarau Bem Black, o grupo tem suas letras-poemas expostas no Myspace, enquanto gravam o primeiro disco, com previsão de lançamento para 2012. Suas canções, que têm como traço mais contundente a imersão rítmica, ritualística e imagética no candomblé, também são muito conhecidas pelos frequentadores do sarau e simpatizantes da cena rap baiana. Ambos autores, dessa forma, não nos oferecem o objeto familiar do livro para que a crítica se faça, mas exigem já o deslocamento para a análise de uma literatura tão nômade quanto os saberes estético-discursivos que ela evoca, já que seus respectivos textos, apesar de conservarem uma base, nunca são os mesmos, seja pelo fator do improviso, seja pela intervenção do público como veremos mais adiante.

O último desafio são as variedades linguísticas a contrapelo da norma dita culta que são utilizadas pelos artistas, independente de sua escolarização, já que mcluhaniamente falando: o meio é a mensagem. Muitas vezes, neste caso, estas variedades linguísticas são entendidas através de uma teoria mimética que a fixa como reflexo da realidade de pouca escolarização, desprezando-se o estranhamento linguístico proposto pelo textopoema. De acordo com Freud, em seu texto Das Unheimilich, o estranho não é aquilo que está fora de algo, mas é o intimamente familiar que é recalcado (FREUD, 2000). Neste caso, essas variedades apontam para aquilo que de mais rudimentar encontramos na língua, porque nem os falantes ditos cultos (aqueles identificados desta forma por ter curso superior completo) são proficientes na variedade ideal da língua calcada na Gramática 174 Número temático: Literatura, cultura e memória negra. A Cor das Letras - UEFS, n. 12, 2011 
Normativa e na variedade linguística de prestígio, subvertendo, como todo bom falante, as prescrições paragramaticais. Ainda assim, muitas vezes, estes mesmos sujeitos atuam como censores da língua disseminando a perversa estrutura panóptica que orienta a questão linguística no Brasil, em que, sobretudo, as minorias sociais são vigiadas ostensivamente. Na canção Mariô, do álbum Nó na orelha, o rapper Criolo (2011), mesmo com um grau de escolarização elevado (chegou a cursar Artes e Pedagogia), avisa aos críticos, ante o seu "dialeto suburbano", que "odeia explicar gíria", remetendo-os a uma tensão desconcertante que exige um redirecionamento analítico, fora das zonas de conforto. Emicida, outro importante rapper da cena brasileira que também chegou ao Ensino Superior, a despeito também de sua escolarização, defende e utiliza em suas canções o "dialeto suburbano", por identificá-lo no rap como importante recurso estético-político, vez que é a variedade linguística na qual os rappers são letrados por outros rappers nas ruas.

Mãe Stella de Oxóssi, Iyalorixá que dirige a comunidade-terreiro do Ilê Axé Opô Afonjá, em artigo publicado no Jornal A Tarde, em 9 de julho de 2011, enfatiza a importância dos provérbios para as comunidades africanas e também para a educação formal brasileira, uma vez que são instrumentos condensadores de uma sabedoria secular que pode ser explorada, inclusive nas salas de aula. Ainda sobre a questão linguística, Amarino Queiroz também adverte para potência da oralidade em suas mais diversas manifestações, para além até de um código linguístico, ao se contemplar outros sons/ruídos que constituem a performance comunicacional, principalmente quando esta envolve a produção de uma arte não alicerçada na escrita (QUEIROZ, 2007).

\section{O QUE É MESMO A LITERATURA-TERREIRO?}

A literatura-terreiro é aquela que, dentro da cosmogonia africana e/ou afrobrasileira, explora a multimodalidade. Ante os grafocentrismo, logocentrismo e etnocentrismo que orientam a constituição dos saberes tradicionais ocidentais, as experiências ex-cêntricas e descentradas de leitura e escrita na comunidade-terreiro e nas expressões que se orientam por sua lógica desconstroem a perspectiva monológica de produção de sentidos. A apropriação e a geração de significados não ocorrem mais de forma exclusiva por meio do código verbal escrito. Ao contrário, cada vez mais, elas se dão por meio de textos construídos a partir da organização multissemiótica em que a dança, a escrita, a música, as figuras etc, em sua co- 
ocorrência indissociável, constituem o que Gunther Kress e Theo Van Leewen (1996) chamam de texto multimodal e aqui nos serve para pensar também na literatura-terreiro como uma literatura multimodal. Nessa confluência de modos comunicativos-artísticos, não há simplesmente contato entre palavra, desenho, cores, gestos, sons, mas interação necessária rumo à significação.

A literatura-terreiro é aquela ainda que está na encruzilhada das literaturas - divergente, maloqueira, marginal, periférica e da litera-rua gravitando, acima de tudo, por entre as experiências de uma militância artística do movimento negro e de uma literatura afrobrasileira. Daí a questão do racismo, da vinculação a uma perspectiva da diáspora negra terem se tornado temas recorrentes nesta literatura-terreiro, convertendo-se numa força, cuja violência fundadora transcende o revanchismo e busca escapar às armadilhas do que Fanon (2008) já chamava de escravidão mental. Assim como quer Nietzsche em relação à história (2003), ela é uma literatura intempestiva: no tempo, contra o tempo e em favor de um tempo vindouro. Por isso, é preciso co-mover-se para lidar com a literaturaterreiro. Seu principal signo: Exu, entidade do panteão das religiões de matriz africana que não pode ser mapeada através das noções de bem e mal. Ele é confundido erroneamente no sistema de leitura dicotômico das religiões judaico-cristãs como diabo, e, justamente por seu ciframento tão sofisticado, ainda ininteligível para parte da crítica artístico-cultural ocidental, é reverenciado do famoso poema Padê de Exu libertador, de Abdias do Nascimento, ao epíteto com que assina Nelson Maca, Poeta Exu Encruzilhador de Caminhos, e ainda na canção Encruzilhada do grupo Opanijé. Exu, além de Senhor dos Caminhos, Dono das encruzilhadas, é o princípio dinâmico da cosmovisão africana presente na cultura yorubá.

Para Eduardo Oliveira (2007), Exu, através da filosofia do paradoxo, impregna todos os seres vivos e "é o princípio de individuação que está em tudo e a tudo empresta identidade. É o mesmo que dissolve o construído; aquele que quebra a regra para manter a regra; aquele que transita pelas margens para dar corpo ao que estrutura o centro; é aquele que inova a tradição para assegurá-la", dessa forma, "mantém um equilíbrio dinâmico baseado no desequilíbrio das estruturas desse mesmo sistema filosóficoético". Por isso, a literatura-terreiro é aquela que, mesmo transcrita, é uma literatura lacunar, mutante, performática que não pode ser literalmente traduzida e aprisionada nas páginas. 


\section{AFRO-GRAFISMOS: VALORES CIVILIZATÓRIOS NEGRO-BRASILEIROS}

O afro-graffiti Ancestralidade: educação atemporal, de autoria de Marcos Costa, como potente expressão dos letramentos negros periféricos no Brasil, traduz um dos nós da rede em que a literatura-terreiro se tece no âmbito do hip hop, deslocando do papel para a parede o suporte de sua escrita-arte na esfera dos valores civilizatórios afro-brasileiros. Justamente pela importância desses valores para o entendimento da literatura-terreiro, faremos algumas breves considerações sobre eles, a seguir.

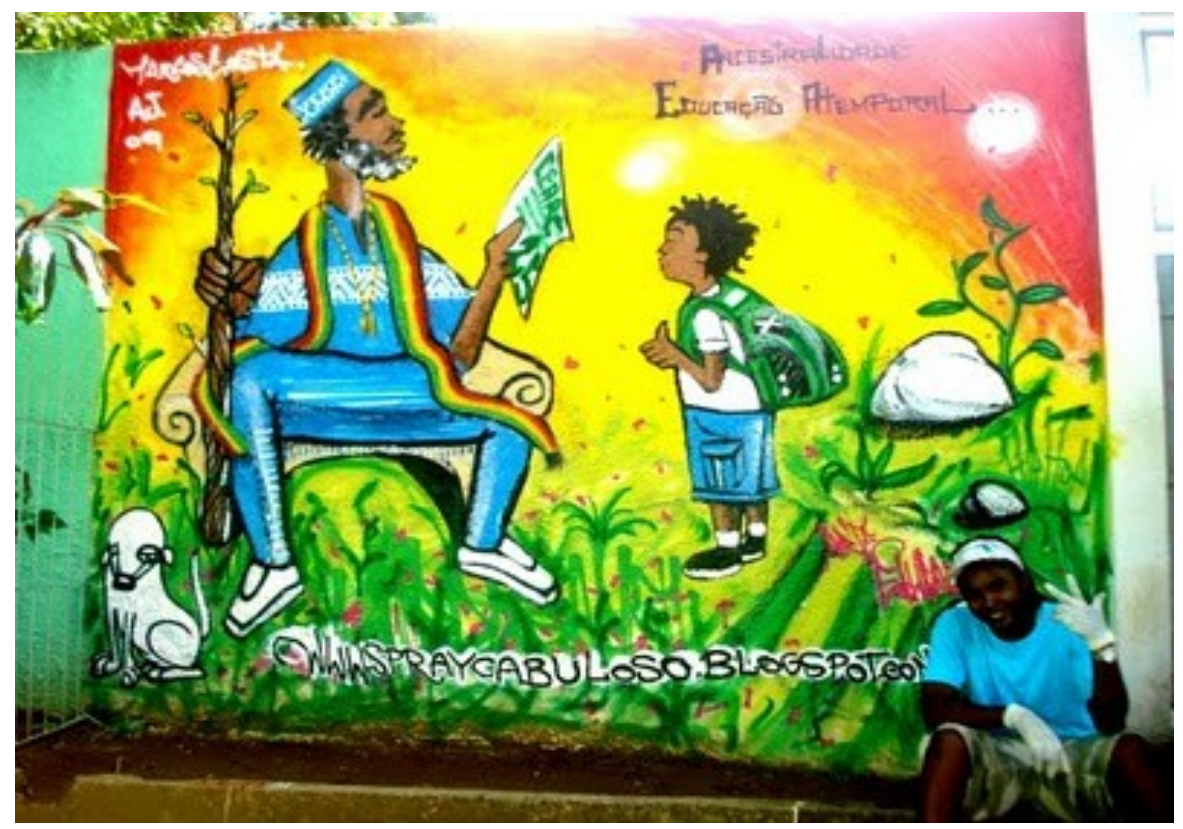

Graffiti Ancestralidade: Educação Atemporal de Marcos Costa (foto) (Fonte: http://spraycabuloso.blogspot.com/)

a) ancestralidade, memória e oralidade - a ancestralidade relaciona-se com outro valor que é a memória e esta não diz respeito apenas a um retorno ao passado, mas à possibilidade de reelaboração das experiências vividas a partir do presente (o princípio da ancestralidade vincula o homem a uma rede que o ultrapassa, já que mesmo os mortos ligam-se a sua existência, a partir do respeito e cultivo a esta memória que vai se tecendo em reverência aos mais velhos - símbolos do saber). É por isso que outro valor 
civilizatório, a oralidade, não pode ser desprezado. O graffiti de Marcos Costa propõe, através de seu texto escrito e imagético, uma conexão entre o conhecimento formal escrito produzido pela escola, simbolizado pelo garoto com a mochila nas costas, e o saber oral ancestral afro-brasileiro transmitido de geração a geração nos mais diversos contextos, representado pelo ancião que, apoiado em um tronco de uma pequena árvore, encarna os nossos griots brasileiros (Abdias do Nascimento, Makota Valdina, Mestre Didi, Mãe Stella de Oxóssi, dentre outros), isto é, nossos "mais veIhos" afro-brasileiros cujos saberes nos formaram e tem nos formado para além de uma educação tradicional;

b) circularidade - é expressa nas rodas de conversa que funcionam diferencialmente como modus operandi no espaço escolar e também extraescolar, porque se organizam a partir de um saber que se assume racializado, por meio de uma movência circular que remonta à cosmogonia africana, à pedagogia dos griots, às rodas de capoeira, às batalhas de break dance (disputas de dança que são realizados círculos nos quais, em pares, os performers vão se desafiando) e mesmo aos xirês (rodas de candomblé), apresentando-se, sobretudo, como método singular para a leitura/escrita. Elas priorizam uma dinâmica lúdica, de co-participação e envolvimento de todos os presentes no círculo. No graffiti analisado, percebemos, por exemplo, o ancião, o menino, o cachorro e a natureza, todos os seres vivos fazendo circular o axé, ou seja, a energia vital que os põe em movimento na roda da vida (isto é insinuado no quadro, por exemplo, através do verde que integra ao mesmo tempo o corpo humano e a natureza). Essa circularidade vinculase também a outro valor civilizatório que é o cooperativismo (o espírito coletivo, de atuação colaborativa em comunidade). Esta intervenção artístico-pedagógica de Marcos Costa, por exemplo, foi realizada de forma integrada às atividades escolares regulares, dentro de um colégio público de Salvador, o Adroaldo Ribeiro Costa, no qual ele interagiu com os estudantes deste espaço educacional;

c) corporeidade - para Eduardo Oliveira, a educação negra deve ser realizada desde o corpo, pois o corpo registra a memória de formas diversas, proporcionando aprendizagens mais complexas que a fixação de informações, daí o canto, a dança, a escrita, a fala possuírem uma relevância na perspectiva tratada aqui. Os corpos 
dos personagens do graffiti são identificados como negros, neste caso, não apenas pelos traços fenotípicos, mas por se apresentarem vinculados a uma filosofia da ancestralidade (OLIVEIRA, 2007) que aponta para uma descrição positiva da negritude. Esse valor atrela-se ainda a outros dois que são a ludicidade, isto é, a consideração dos jogos no processo educativo, e a musicalidade através dos ritmos que formam e narram o corpo negro positivamente através dos sons e gêneros musicais;

d) religiosidade e energia vital- mais que religião, a religiosidade aqui está conectada com outro valor civilizatório que é o axé, ou seja, a energia vital: vontade de viver e aprender sem barreiras. A religiosidade diz respeito à forma como nos dedicamos a outra pessoa. No graffiti de Marcos Costa, vemos o princípio do axé, na simbologia das vestes do senhor idoso, bem como a lógica da religiosidade na forma respeitosa com que este ancião e o garoto parecem dialogar. Isto também se expressa na harmonia entre espaço natural e cultural que não aparecem separados, mas como se fossem apenas um.

A compreensão dos valores civilizatórios afro-brasileiros nos auxilia na tarefa de entendermos melhor como opera a literatura-terreiro, já que eles constituem a força motriz de sua gênese e, por isso, podem facilmente ser observados tanto no fragmento da música do Opanijé quanto no poema e nas ações de Nelson Maca, os quais apresentaremos no capítulo a seguir.

\section{A LITERATURA-TERREIRO NA ROTA DA DIÁSPORA AFRICANA}

Para tornar mais nítidas as observações que aqui fizemos, apresentaremos primeiro o poema de Nelson Maca. No Sarau Bem Black, ele é recitado pelo autor com o auxílio do músico e poeta underground da cena soteropolitana, Robson Véio, que vai, aos poucos, tensionando a carga dramática do texto, simplesmente através da repetição da frase "-Calma, rapaz!" com entonações diferentes, ao que o público frequentador do sarau, ciente da performance que orienta a cena, acompanha-o, intervindo autoralmente no poema a cada rodada:

Então eu resolvi afundar os negreiros

Afogar capitães e marinheiros do empreendimento

No mesmo sal do mar que me sugava os restos corroídos

Foi quando esta voz sussurrou ao meu ouvido: 
- Calma, Rapaz!

Então eu resolvi alvejar a cabeça do capitão do mato

Para dominar o campo de batalha em que eu vivia

Com o mesmo trabuco que me atingia as costas

quando eu fugia

Foi quando esta voz sussurrou ao meu ouvido:

- Calma, Rapaz!

Então eu resolvi cortar a garganta da princesa de maio

Para exterminar de vez as falácias da abolição

Com a mesma navalha que me decepava os dedos

de negro fujão

Foi quando esta voz sussurrou ao meu ouvido:

- Calma, Rapaz!

Então, eu resolvi sequestrar o dono da fábrica

Para reparar as deficiências do meu salário que é o mínimo

Com a mesma neutralidade que me seqüestraram

a força ativa

Foi quando esta voz sussurrou ao meu ouvido:

- Calma, Rapaz!

Então eu resolvi socar a boca do primeiro filho da puta que aparecesse

Para sangrar a oligarquia dos que sempre nos calam

Com o mesmo punho cerrado que sempre nos socaram

Mas esta voz ainda sussurrou ao meu ouvido:

- Calma, Rapaz! Calma, Rapaz!

Take it easy my brother Charles, take it easy meu irmão de cor!

(Nelson Maca, no blog Gramática da Ira, 2011).

No poema acima, os valores civilizatórios afro-brasileiros vão sendo encenados um a um no eterno retorno em diferença do confronto da voz insurrecta às forças coloniais que oprimiram africanos e afrodescendentes no Brasil com a voz espectral, consciência coletiva ancestral, que cobra uma reflexão do eu-revolucionário antes da reação abrupta à violência histórica sofrida: - Calma, rapaz! Este duplo que marca todo o poema é símbolo da encruzilhada em que se encontra o próprio poeta no trânsito entre suas 180 Número temático: Literatura, cultura e memória negra. A Cor das Letras - UEFS, n. 12, 2011 
atividades docentes universitárias e seu ativismo nas ruas. Um dos grandes articuladores da cena hip hop soteropolitana, através do Coletivo Blackitude - Vozes Negras da Bahia, Nelson Maca é professor de literatura da Universidade Católica de Salvador e coordenador de dois saraus literários: o sarau infantil Bem Legal, que ocorre mensalmente na Biblioteca Monteiro Lobato, e o Sarau Bem Black, que acontece no Pelourinho. Crítico arguto do movimento hip hop ${ }^{6}$, está sempre envolvido em produções relevantes para esta cena no Brasil, como o lançamento do DVD Cartão Postal Bomba (2009) e a produção do livro A rima denuncia (2010), ambos de GOG, Genival Oliveira Gonçalves, rapper considerado uma das pedras fundamentais do hip hop no Brasil. O sarau Bem Black, aliás, é ponto de encontro do pivete que vende bala e sobe ao palco para tirar uma fita soltando uma rima, da galera do Movimento Negro, dos poetas com e sem livros publicados, dos diretores e atores do teatro baiano, de músicos do movimento hip hop, mas também de outras cenas musicais; dos intelectuais periféricos que circulam para se divertir e também pesquisar desde o corpo. Assumidamente filho da COOPERIFA (Cooperativa Cultural da Periferia, organizado em São Paulo pelo escritor Sérgio Vaz), o Sarau Bem Black já tece seus rizomas em Salvador nas Sextas Poéticas, sarau dos jovens estudantes do Instituto de Letras da Universidade Federal da Bahia, no Sarau da Mata, que acontece no bairro de Mata Escura, e no Sarau da Onça, que ocorre no bairro de Sussuarana.

"Ouçamos" agora a canção Encruzilhada do grupo Opanijé, cujo nome alude à Organização Popular Africana - Negros Invertendo o Jogo Excludente, bem como à dança sagrada dedicada ao orixá Obaluê que é guiada por uma batida-percussiva-ritual muito singular:

Encruzilhada

(Lázaro/Dum Dum/Heider)

Acharam que nos derrotaram, que tinham todos na mão

Pensaram que nos derrubaram, que não ia ter reação.

Mentiram dizendo que a gente não tinha historia ou passado

Feriram nossa identidade falando que a gente cultua o diabo

Serviram nossa auto estima na bandeja aos porcos

E riram dizendo que nossos deuses estavam mortos

Cortaram nossa raiz desde cedo,

Arrancaram nosso cordão umbilical,

6 Cf. www.gramaticadaira.blogspot.com. - Blog de Nelson Maca em que ele divulga eventos e posta regularmente seus textos sobre o movimento hip hop nacional. 
Fizeram o povo todo ter medo,

Nos deram uma condição marginal,

Mas chega!

Nem todos se rendem a qualquer esperto

Pensaram que eu tava sozinho, mas não, tô bem coberto.

Eu prego a palavra dos puros, dos que tão em apuros

Minha rima o sangue estanca, roupa branca, corpo escuro

Sozinho cê toma susto vendo vulto, tá de luto

A sua desonra sumiu na fumaça do charuto

Porque já tentou escravizar com ilusões

Mas na encruzilhada temos várias opções

O caminho, a verdade e a vida, como é que fica?

Entre a terra e o céu me diz, quem é que comunica?

Exu nasceu no Jitolu, não teme nada

Mora na comunidade, a encruzilhada é sua morada

Aquele que comunica, frutifica e faz crescer

Não tenho nada a dizer a não ser... (Laroiê!)

Quatro elementos pra mim ainda são poucos

Levo meu ideal a sério com a corda no pescoço

Não sufoca, não amarra,

Não enforca, não cala.

Sou um bom orador e minha função é minha palavra

Representei os quatro cantos do mundo fiz revolução

Com a tradição oral de que a África não abre mão

Recitado nos poemas periféricos, com bastante sentimentos

Utilizo como chave boas ações, bons argumentos.

Pensar o conceito de diáspora africana ou de diáspora negra na contemporaneidade exclusivamente como uma dispersão imputada por uma esfera político-cultural dominante é tornar invisível a resistência, as contranarrativas e as produções realizadas pelos africanos e afrodescendentes desde que o Atlântico tingiu-se de negro, funcionando como rota de passagem para o tráfico de escravos. Neste sentido, o afrograffiti de Marcos Costa, mas, sobretudo, a canção Encruzilhada do Opanijé, bem como o texto do poeta Maca, Encruzilhador de Caminhos, ao tomarem o orixá Exu como eixo de suas literaturas-terreiro para reescrever a história de africanos e afro-brasileiros, conectam-se com o sentido mais potente de diáspora negra.

De acordo com Paul Gilroy (2001), na complexa rede de relações que se originou com a mistura e o movimento de diversas culturas que cruzaram e cruzaram-se por meio da travessia compulsória do oceano, a diáspo182 Número temático: Literatura, cultura e memória negra. A Cor das Letras - UEFS, n. 12, 2011 
ra negra passa a ser entendida através das semelhanças e dos sentimentos de solidariedade provocados pelas experiências de desterritorialização e reterritorialização dos povos em trânsito.

A diáspora abala, assim, a perspectiva essencializante de unanimidade racial e de tratamento dos negros como se fossem exatamente idênticos, questionando os modelos de classificação que foram usados para os africanos e afrodescendentes durante a colonização e também após este período, já que ela afeta uma idéia de origem e de identidade únicas, compreendendo o homem e a mulher negros como seres complexos, constituídos de múltiplas raízes, de matrizes diversas e fragmentadas.

Stuart Hall em Da diáspora (2003), ao refletir sobre a cultura caribenha, fala da ineficiência de se pensar a cultura negra com base em modelos orientados pela idéia de origem/cópia, destacando que as culturas da diáspora tem que ser compreendidas em suas relações com outros povos da diáspora e não apenas com a África. Logo, na realidade brasileira, retrabaIhar a África foi e continua sendo um exercício potente para as políticas e expressões culturais dos sécs. XX e XXI. Daí, a relevância ainda maior para os trabalhos que tomamos como base para este texto.

A condição diaspórica é capaz de conferir criatividade e de gerar satisfação, oferecendo as bases para se transgredir o poder e o saber que tentaram ou que ainda tentam colonizar os afrodescendentes espalhados pelo mundo: a capoeira, a música afro-brasileira e a literatura-terreiro de que tratamos especificamente neste texto são exemplos desta experiência; as religiões de matriz africana e as redes de sociabilidades negras construídas no Brasil, como as irmandades, são também grandes modelos desta condição diaspórica. Elas operam a partir da transformação da experiência traumática de um passado colonial escravocrata em arte, em formas de empoderamento dos afrodescendentes e de sua cultura na diáspora, fazendo com que as raízes negro-africanas espraiem-se ainda mais produtivas pelo mundo.

\section{CONSIDERAÇÕES FINAIS - NÃO HÁ DIALÉTICA NA ENCRUZILHADA}

A literatura-terreiro não é uma literatura sobre as religiões de matriz africana ou que etnograficamente a utilizam como mote. Ela é aquela que se escreve desde o corpo e, de acordo com Eduardo Oliveira, reconhece o corpo como "filosofia encarnada, literatura em movimento" (OLIVEIRA, 2007). 
Sem corpo, não há literatura-terreiro, já que, na cosmovisão africana, ele congrega múltiplos significados, sendo a base da interação entre os seres. O corpo na literatura-terreiro se apresenta como ancestral, isto é, como uma anterioridade, já que ancestral nem sempre é o mais velho em termos etários.

A ética, a estética, o conteúdo e a forma gravitam num xirê7 de sentidos na literatura-terreiro. Tudo isso guiado pelo tambor, que marca os poemas de Nelson Maca e também as músicas-poemas do Opanijé. O tambor aqui torna-se ele mesmo poesia suplementar do griotismo dos poetas africanos, conforme observa Hampâté Bâ, mas também dos poetas afrodiaspóricos brasileiros do canto-falado, que, através de suas estratégias mnemônicas, tecem as tradições, por meio da poesia dub e do rap, por exemplo, de acordo com as reflexões de Amarino Queiroz (2007).

Paul Zumthor (1997), em Introdução à poesia oral, afirma que a privação dos tambores pode mesmo fazer ruir uma tribo, por isso alguns povos escravizados na América foram proibidos de usá-los tão logo os senhores perceberam que havia uma gramática da resistência extremamente eficiente, que era ininteligível aos senhores e, ao mesmo perigosa para a estrutura colonial. Além disso, ele afirma ainda que "[...] a percussão constitui estruturalmente uma linguagem poética" (ZUMTHOR, 1997).

Sobre os tambores, é preciso ainda recuperar o que disse Sérgio Vaz no Manifesto da Antropofagia Periférica, porque a periferia não é mais só objeto de estudo, ela produz também críticos argutos de literatura:

A favor do batuque da cozinha que nasce na cozinha e sinhá não quer. Da poesia periférica que brota na porta do bar.

Do teatro que não vem do "ter ou não ter...". Do cinema real que transmite ilusão.

Das Artes Plásticas, que, de concreto, quer substituir os barracos de madeiras.

Da Dança que desafoga no lago dos cisnes.

Da Música que não embala os adormecidos.

Da Literatura das ruas despertando nas calçadas (Sérgio Vaz, no blog O colecionador de pedras, 2011).

Por fim, apenas uma advertência: não há dialética na encruzilhada. Nela, subsumem todas as sínteses possíveis, já que, no emaranhado de percursos que se atravessam em dado ponto, Exu é a própria pulsão da

7 Roda na qual os integrantes das religiões de matriz africana dançam durante alguns rituais.

184 Número temático: Literatura, cultura e memória negra. A Cor das Letras - UEFS, n. 12, 2011 
tensão, da contradição, ou melhor, da contradicção que move a palavra contra sua ordem grafocêntrica.

Não há dialética na encruzilhada, portanto nem Hegel, nem Marx: só charuto, uma boa farofa e cachaça ${ }^{8}$... Dessa forma, resta-me apenas saudar Exu, para que, na cena provisória do fim desta apresentação, outros caminhos se abram: Laroiê! !

\section{REFERÊNCIAS}

CARTÃO Postal Bomba. Direção e produção: GOG, Ariel "Haller" Feitosa e Angel Duarte. Brasília: Só Balanço, c 2009. 1 DVD (130 min), color. Produzido por: Só Balanço.

FANON, Frantz. Pele negra, máscaras brancas. Tradução de Renato Silveira. Salvador: EDUFBA, 2008.

FERRÉZ. (Org.). Literatura marginal: talentos da escrita periférica. Rio de Janeiro: Agir, 2005.

FREUD, Sigmund. Das Unheimliche. In: Idem. Edição eletrônica brasileira das obras psicológicas completas de S. Freud. Rio de Janeiro: Imago, 1998.

GILROY, Paul. O Atlântico negro: modernidade e dupla consciência. Trad. Cid Knipel. São Paulo: Ed. 34; Rio de Janeiro: Universidade Cândido Mendes, Centro de Estudos Afroasiáticos, 2001.

GOG. A rima denuncia. São Paulo: Global, 2010.

GRAFITTI: Ancestralidade: educação atemporal. Disponível em: http://spraycabuloso.blog spot.com. Acesso em: 23 jan. 2012.

GRAMÁTICA da IRA. Disponível em: http://gramaticadaira.blogspot.com/. Acesso em: 23 jan. 2012.

HALL, Stuart. Da diáspora: identidades e mediações culturais. Org. Liv Sovik. Trad. Adelaine La Guardia Resende et al. Belo Horizonte: Ed. UFMG; Brasília: Representação da UNESCO no Brasil, 2003.

KRESS, Gunther; VAN LEEUWEN, Theo. Reading Images: The Grammar of Visual Design. Londres: Routledge, 1996.

LIMA, Vivaldo da Costa. Lessé Orixá: nos pés do santo. Salvador: Corrupio, 2010.

MIGNOLO, Walter. Histórias locais/projetos globais: colonialidade, saberes subalternos e pensamento liminar. Trad. de Solange Ribeiro de Oliveira. Belo Horizonte: Ed. UFMG, 2003.

NIETZSCHE, Friedrich. Segunda consideração intempestiva: da utilidade e desvantagem da história para a vida. Trad. Marco Antônio Casanova. Rio de Janeiro: Relume-Dumará, 2003.

OLIVEIRA, Eduardo David. Cosmovisão africana no Brasil: elementos para uma filosofia afrodescendente. Fortaleza: LCR, 2003.

8 Elementos que compõem oferenda para Exu.

9 Saudação a Exu. 
OLIVEIRA, Eduardo David. Filosofia da ancestralidade: corpo de mito na filosofia da educação brasileira. Curitiba: Ed. Gráfica Popular, 2007.

OXÓSSI, Mãe Stella de. Balaio de ideias: poucas palavras, muita sabedoria. Disponível em: http://www.atarde.com.br/mundoafro/?tag=proverbios . Acesso em: 1 ago. 2011.

QUEIROZ, Amarino Oliveira de. As inscrituras do verbo: dizibilidades performáticas da palavra poética africana. Tese (Doutorado em Teoria da Literatura). Recife: UFPE, 2007.

ZUMTHOR, Paul. Introdução à poesia oral. Trad. Jerusa Pires Ferreira, Maria Lúcia Pochat e Maria Inês de Almeida. São Paulo: Hucitec, 1997.

A COR da cultura. Valores civilizatórios afro-brasileiros. Disponível em: http://www.acorda cultura.org.br. Acesso em: 26 jan. 2012.

VAZ, Sérgio. Manifesto da antropofagia periférica. Disponível em: http://revistaraiz.uol. com.br/portal/index.php?option=com_content\&task=view\&id=762\&Itemid=190. Acesso em: 10 jul. 2010.

VAZ, Sérgio. Manifesto da antropofagia periférica. Disponível em: http://colecionadorde pedras1.blogspot.com/2010/04/manifesto-da-antropofagia-periferica.html. Acesso em:26 jan. 2012. 